Nemanja Vuksanovićc
Ljubinka Joksimović
Dragan Aleksić $^{3}$
JEL: 121, 126, J08

DOI:10.5937/industrija46-16199

UDC: 336.531.2:37.014.5(497.11)

Original Scientific Paper

\title{
School to work transition in Serbia: returns to investment in education of youth
}

Article history:

Received: 4 January 2018

Sent for revision: 15 January 2018

Received in revised form: 12 February 2018

Accepted: 12 February 2018

Available online: 20 March 2018

\begin{abstract}
The subject of the paper is estimation of a rate of return to investment in education of youth in Serbia. The aim of the paper is to determine, on the basis of the data from the School to Work Transition Survey (SWTS) from 2015, a premium for the education of persons from 15 to 29 years old. A rate of return to investment in education for youth is estimated using the least squares method and using the instrumental variables method. As the instruments for a variable that refers to the number of years of education were used a father's level of education and a mother's level of education. The results of the assessment using the least squares method indicate that a rate of return to investment in education for youth in Serbia is $5.2 \%$. The value of the coefficient in the case of evaluation by the instrumental variables method is twice as big as in the case of the least squares method. It is confirmed that in the case of the assessment using the least squares method we get a biased assessment. This result also suggests that schooling of children in Serbia continues to serve as a family characteristic, and informs that the education system in Serbia cannot provide a fair access to schooling for those children coming from socio-economic vulnerable families.
\end{abstract}

Keywords: education, investment, return on investment, transit, youth.

\footnotetext{
${ }^{1}$ University of Belgrade,Faculty of Economics, vuksanovic@ekof.bg.ac.rs

2 University of Belgrade, Faculty of Economics.

${ }^{3}$ University of Belgrade, Faculty of Economics. 
Vuksanović N. et. al.: School to work transition in Serbia: returns to investment in...

\title{
Tranzicija od škole do posla u Srbiji: stopa povraćaja na ulaganje u obrazovanje za mlade
}

\begin{abstract}
Apstrakt: Predmet rada jeste ocena stope povraćaja na ulaganje u obrazovanje mlade populacije u Srbiji. Cilj rada jeste da se na osnovu podataka Ankete o tranziciji od škole do posla iz 2015.godine utvrdi premija na obrazovanje lica starosti od 15 do 29 godina. Stopa povraćaja na ulaganje u obrazovanje mladih ocenjena je primenom kako metode najmanjih kvadrada, tako $i$ upotrebom metode instrumentalnih promenljivih. Kao instrumenti za promenljivu koja se odnosi na broj godina školovanja korišćeni su obrazovni nivo oca i obrazovni nivo majke. Rezultati ocenjivanja metodom najmanjih kvadrata ukazuju na to da stopa povraćaja na ulaganje u obrazovanje mladih u Srbiji iznosi 5,2\%, dok prema rezultatima ocenjivanja metodom instrumentalnih promenljivih ova stopa iznosi 9,3\%. Kako je stopa povraćaja na ulaganje u obrazovanje dobijena korišćenjem metode instrumentalnih promenljivih veća u odnosu na stopu povraćaja na ulaganje u obrazovanje koja je dobijena korišćenjem metode najmanjih kvadrata, potvrđuje se da se u slučaju ocenjivanja metodom najmanjih kvadrata dobijaju pristrasne ocene. Ovakav rezultat takođe ukazuje na to da je školovanje dece u Srbiji i dalje u funkciji karakteristika porodice iz koje deca potiču, $i$ sugeriše na to da obrazovni sistem u Srbiji ne uspeva da obezbedi pravičan pristup školovanju onoj deci koja dolaze iz socio-ekonomskih ugroženih porodica.
\end{abstract}

Ključnereči: obrazovanje, ulaganje, stopa povraćaja na ulaganje, tranzicija, mladi.

\section{Introductory considerations}

The starting point in the analysis of the economic role of education in the labor market represents the human capital theory, founded on the papers of Schultz (1961), Mincer (1974) and Becker (1975). From the aspect of the human capital theory, education contributes to increasing the productivity of an individual. Consequently higher income of an individual in the future is the result of higher productivity. The human capital theory assumes that there is no information asymmetry between employee and employers, and that individuals rationally choose to invest in education so the potential benefits of education are equal to the expected costs during education. Thus, education is seen as an investment activity which contributes to increasing the productivity of an individual (Vuksanovic and Aleksic, 2017).

The formulation of the human capital theory, in the 1960s and 1970s, prompted the publication of dozens of papers (e.g. Psacharopoulos, 1973, 1985, 1994, Freeman, 1976, Goldin and Polacheck, 1987, Chiswick, 1988, 
Vuksanović N. et. al.: School to work transition in Serbia: returns to investment in...

Krueger, 1993, Jensen, 2010; King, Montenegro, and Orazem, 2012) where researchers estimated a rate of return to investment in education. In these papers, researchers have sought to identify the value of educational investments, with the aim of determining the optimum investment of individuals at different levels of education. The significance of this type of account is reflected in the fact that the results of these research is often used to justify the country's interventions in the field of education. Namely, the established positive link between the educational level and the future salary of an individual was used in the distributional effects analysis of financing various educational programs, which allowed the creators of educational policies to create incentives for promoting both private and public educational investments. Therefore, understanding how to assess returns to schooling and being able to appropriately apply those results to policy decisions is a critical skill for educational policymakers to have at their disposal (Patrinos, 2016).

The rate of return estimation to investment in education vary considerably depending on (1) the data used, (2) the initial assumptions, and (3) the assessment method that has been applied. Attempts to evaluate the unique rate of return on investment in education can be informative useless if the rate differs by educational levels or by groups within the population. Also, a particular methodological challenge represents a potential endogenous problem, which often requires assumptions that cannot be empirically tested or, at best are sensitive to empirical robustness tests. Moreover, economists often do not take into consideration a risk associated with the so identified values of educational investment (Harmon, et al., 2003). Nevertheless, despite these methodological challenges researchers are facing when examine the link between the educational level and the future salary of an individual, several consistent conclusions can be drawn from the numerous papers devoted to this topic. According to the World Bank Report the following conclusions are outlined: (1) a rate of return to investments in education is positive and on average, by country, is $10 \%$ per year of education; (2) a rate of return to investment in education is higher in underdeveloped countries and countries in transition than in developed countries; (3) a rate of return to investment in education is increasing with the growth of the educational level of an individual, so it is the highest for individuals with higher education (until recently the prevailing attitude was that a rate of return to investment in education is the highest for individuals with elementary education but the results of recent studies in which determined premium on education contributed to such a turnaround); (4) a rate of return to investment in education is higher in the case of women than in the case of men; (5) rates of return on investment in education are slowly falling down over time despite the growing average number of years of schooling at a global level, suggesting that demand for skills has been growing at the same time as 
Vuksanović N. et. al.: School to work transition in Serbia: returns to investment in...

offering skills (Montenegro and Patrinos, 2014). However, the International Labor Organization Report points out that in a relatively small number of studies has outlined the fact that different age groups within the population receive different education premiums. In this regard, a small portion of the papers is devoted to assessing a rate of return to investment in youth education (Sparreboom and Staneva, 2014).

The most significant global social changes in the labor market, such as the change in country regimes and policies resulted from the collapse of socialist policies, the crisis of the state welfare and neoliberal regimes, have essentially influenced the lives of young people. Disorders in labor market have produced, in addition to uncertain and turbulent transitions, some new forms of inequality alongside the old ones that survive (Furlong, Cartmel, 2007). Growing interest in the position of youth in the labor market has been encouraged in recent years by the fact that young people form a group that is more at risk of the threat of poverty and social exclusion, and that the unsuccessful transition from school to work can have unexpected negative consequences for other life transitions. The global changes since the 1970s have contributed to rising unemployment and making it difficult for young generations to enter the labor market. The transition from school to work increasingly loses its standard shape and becomes prolonged and fragmented (Du Bois-Reymond and Chisholm, 2006). In most countries, the unemployment rate of young people is almost twice as high as the total unemployment rate. As stated in the Labor Market Research article, this can be explained by the fact that lack of work experience and weaker job search skills, as well as structural problems such as inadequate education and training and restrictive labor market regulation, are the root causes for such high rates of unemployed youth. Therefore, the analysis of the transition of young people from the moment of completing their education to the time of finding a job becomes important. One of the aspects of this analysis which attracts special attention to the researchers is the assessment of the return rates of investments in the education of young people (Kluve, 2014).

The youth employment crisis presents a particular challenge for Serbia, although its social and economic characteristics vary significantly in terms of intensity and nature, depending on gender and location. Furthermore, this employment crisis could also be seen as one aspect of the job crisis. In this sense, it is linked not only to the level and duration of youth unemployment in the labor market but also come from decrease in the quality of jobs available to young people.We witness the pushing of young workers that lose out jobs and young entrants to labour market in direction of precarious jobs. That fact, at large will shape their opportunities in sense of carrier development, adequate living standards, their children's future and overall social inclusion of young people (Joksimovic and Vuksanovic, 2017). 
Vuksanović N. et. al.: School to work transition in Serbia: returns to investment in...

The subject of the paper is estimation of a rate of return to investments in education of youth in Serbia. The aim of the paper is to determine, on the basis of the data from the School to Work Transition Survey (SWTS) from 2015, a premium for the education of persons from 15 to 29 years old. The importance of the paper is reflected in the fact that, as far as the authors are aware, this is the first research of this kind, since so far in several studies, a rate of return to investing in education for the total population in Serbia has been exclusively assessed. The structure of the paper consists of 6 parts. After introductory considerations, the second part discusses the transition from school to work in Serbia. Namely, there are some basic indicators related to the position of young people in Serbia in the labor market. The third part describes the methodology used in a rate of return to investment in youth education in Serbia. Here is presented a model of the regression equation that is evaluated, the changes that are included in the model and the methods used for evaluation. The fourth part is devoted to the description of the data used in the research. In the fifth section, the results of analysis of the research are presented. The last part of the paper is a conclusion.

\section{Youth in Serbia}

When it comes to young people, most commonly it's referred to one of the two definitions: (1) narrower - which includes people from 15 to 24 years; and (2) broader - those from 15 to 29 years old. The first definition is most often used to analyze the position of young people in the labor market according to the methodology of an internationally standardized questionnaire, i.e. Labor Force Survey, while the second definition corresponds to the formulation stated in the National Youth Strategy of the Republic of Serbia, mainly used by the Ministry of Youth and Sports and the National Employment Service. Considering this research is based on the questionnaire of the School to Work Transition Survey, conducted as an ad-hoc addition to Labor Force Survey, the analysis in this paper is based on a broader definition of young people since by the aforementioned questionnaire were covered people from 15 to 29 years old.

The worldwide attention to the topic of youth employment and the extensive research carried out on this topic have helped to raise a level of awareness of the fact that a significant number of young men and women today face difficulties in entering and subsisting on the labor market. Also, according to the public policymakers, there is a noticeable growth in understanding that fail to find quality employment after finishing schooling contributes to long-term negative effects when it comes to the earnings that a person can achieve during his lifecycle (Elder, 2009). This become more conceivable by realizing that transition from school to work represents a very important segment of 
Vuksanović N. et. al.: School to work transition in Serbia: returns to investment in...

transition to growing up, whose success largely predetermines the success of other segments in youth growing up. For instance, a family transition depends on the way in which the young person will complete from school to seeking a job transition, which relates to young people's decisions on being independent of parents, getting married and parenting (Tomanovic et al., 2012). Finishing education and searching for a job are two very important moments in the life of a young person. After years spent in school, young people tend to find employment that will suit their preferences and where they will be able to apply the knowledge gained during their education. However, today's transition from school to work is characterized by great uncertainty, therefore, entry into the labor market for many young people across Europe is a major challenge and searching for suitable employment can be a long-lasting process (Eurofound, 2014). In certain European countries, such as Austria, Germany, Denmark or the Netherlands, policymakers are able to identify the manner for integrating young people into their labor market. In some other European countries, this is not the case. This suggests that, even though transitional templates can partially explain the preferences of individuals, different institutions are what determines the ease of the transitional path in fact. In the literature, several factors have been identified in a given country allowing young people to easily transition from school to work: (1) favorable demographic structure and macroeconomic situation; (2) high demand for young workforce; (3) dual labor markets and co-related employment protection; (4) the education and training system which provides young people with the necessary knowledge and prepares them for entry into the labor market; (5) social regimes that include active labor market programs (Biavaschi et al., 2012).

\section{Image 2.1: Percentage of young population in Serbia by age and sex} according to the census data from 2011.

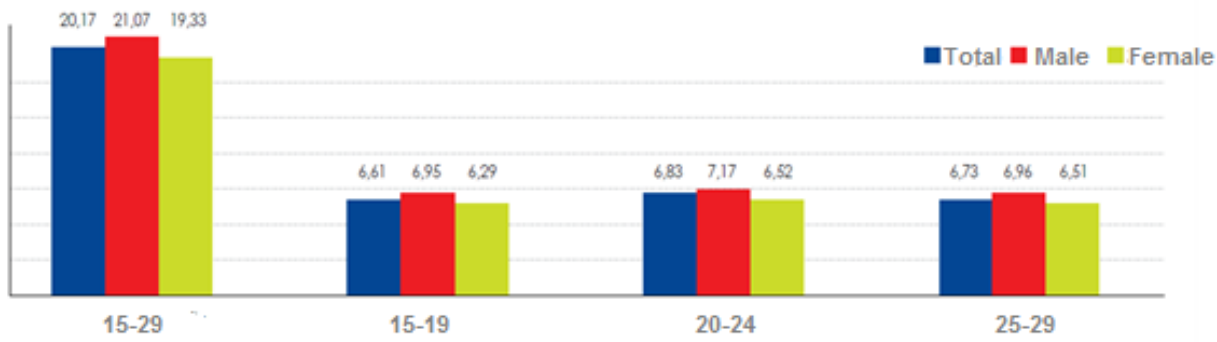

Source: Tomanovic et al. (2015)

In Serbia, according to the census data from 2011, the percentage of the young population was about $20 \%$, with a slightly higher percentage of men than women. Therefore, young population is by no means marginal but it represents a significant labor potential of the country. The percentage of young people in Serbia is about 2 percent points higher than in the European 
Vuksanović N. et. al.: School to work transition in Serbia: returns to investment in...

Union countries, which classifies Serbia in younger European countries. Therefore, the analysis of the transition of youth in Serbia from school to work should be given great importance.

According to the Statistical Office of Serbia, in 2015 almost $51 \%$ out of the total number of young people in Serbia were still in the process of education. In other words, it can be said that almost half of the young people in Serbia have begun or completed the transition process from finishing school to finding a job. The educational structure of young adults in Serbia, which is presumed to have completed the education process, was as follows: elementary education and lower than elementary education has $16.5 \%$, high school education has 59\%, and high and higher education has $24.5 \%$. Regarding the educational structure in the European countries, there are two extremes: (1) at one end of the continuum there are countries, such as Portugal and Turkey, in which almost half of young people have only completed elementary education or lower than elementary education, (2) while at the other end of the continuum there are countries such as France or Sweden, where more than a third of young people have completed high or higher education. Serbia, according to the above data, is closer to this second extreme.

However, from the perspective of young people, formal education paradoxically becomes increasingly centralized and marginalized (Wyn, 2009). Formal education is still highly valued, because it represents the human capital necessary to secure employment. Simultaneously it is shown to be insufficient, because the strategies of transition from school to work need to include necessary skills acquired in the processes of informal education, and which are more and more valued (Tomanovic et al., 2015). Also, the results of the research Young People in Serbia (2015) clearly show narrow channels of educational upward mobility: every fifth young person whose parents have elementary education has only completed elementary school, and one in ten has succeeded in completing a college or faculty. According to the results of the same research, it is interesting to perceive some downward: almost half of young people with high education have a lower educational status than one of their parents.

The sphere of education, as well as the sphere of employment, have stood significant transformations. Part of these changes is a structural nature, and it relates to the restructuring the global labor market in post-industrial society and the inability to integrate new contingents of the young labor force into the economic reproduction of society. The uncertain and unpredictable labor market eliminates the possibility of a standard transition path from school to work, making it delayed and prolonged (Mortimer, 2009). The last major economic crisis of 2008 was also negatively contributed to the difficult transition to the labor market, and mostly young people were affected by the 
Vuksanović N. et. al.: School to work transition in Serbia: returns to investment in...

consequences. At the time of the economic crisis, due to a lack of demand for labor force and due to a need for reducing the costs, the companies were firing people, often those who were the last to hire.

Although young people almost everywhere are encountering certain problems during the transition from school to work recently, these problems are particularly pronounced in Serbia, according to the World Bank Report (2006). In support of this statement, data represented by the Statistical Office of Serbia and relating to the employment rate and unemployment rate, both for the total population and for the young population, in the period from 2008 to 2015. give robust evidence.

Table 2.1: Employment rate and unemployment rate for the total population and young population in Serbia in the period from 2008 to 2015 (in \%)

\begin{tabular}{|c|l|c|c|c|c|}
\hline \multicolumn{2}{|c|}{} & 2008 & 2010 & 2013 & 2015 \\
\hline \multirow{2}{*}{\begin{tabular}{c} 
Employment rate \\
\cline { 2 - 6 }
\end{tabular}} & Total population (from 15 to 64 years old) & 53,7 & 47,2 & 47,5 & 52,0 \\
\cline { 2 - 7 } & Young population (from 15 to 29 years old) & 33,4 & 25,7 & 26,2 & 31,8 \\
\hline $\begin{array}{c}\text { Unemployment } \\
\text { rate }\end{array}$ & Total population (from 15 to 64 years old) & 14,4 & 20,0 & 23,0 & 18,2 \\
\cline { 2 - 6 } & Young population (from 15 to 29 years old) & 28,6 & 38,8 & 41,5 & 30,8 \\
\hline
\end{tabular}

Source: Authors' calculation

The youth employment rate in Serbia was around $33 \%$ in 2008 , while this rate was slightly less than $32 \%$ in 2015 . This indicates that the youth employment rate has not even reached the level before the outbreak of the economic crisis. Moreover, when the negative effects of the economic crisis weakened, the employment rate of young people in Serbia was twice lower than the employment rate of young people in the European Union, where on average it was about $45 \%$ in 2013 . It is noticeable that the employment rate for the young population in Serbia in 2015 was around 20 percentage points lower than the same rate for the total population. A specifically difficult position of young people in the Serbian labor market is also indicated by the fact that the youth unemployment rate in 2015 was about $31 \%$ and was higher by about 2 percentage points than in 2008. It can also be noted that the unemployment rate of the young population throughout the observed period was 1.5 to 2 times higher the unemployment rate of the total population. Although deviations of the labor market indicators between the young population and the total population is characteristic for other countries of the European Union, the level of these deviations is worrying in Serbia. Economic policymakers have recognized the complexity of the position of young people as well as the further deterioration of their position caused by the economic crisis, and in 2013 , they adopted a package of measures to help young people in the labor market by using a model such as paneuropeanprogramme Youth Guarantee. 
Vuksanović N. et. al.: School to work transition in Serbia: returns to investment in...

The main idea of a package of youth-oriented measures was based on intensifying cooperation between the National Employment Service and the unemployed young people through: (1) assessment of the employability of persons registered in the records, (2) establishment of an individual employment plan, and (3) mediation in employment or inclusion in measures of an active employment policy that can contribute to employment (Marjanovic et al., 2016). However, the results achieved by the aforementioned package did not meet the expectations of the economic policymaker, since in 2015 there was no significant improvement in the position of the young population on the labor market, observed through the employment rate and the youth unemployment rate, compared to 2008.

The results of the research Young people in Serbia (2015) state that out of the total number of young people who completed the education process, $37.2 \%$ are stable employees, $29.1 \%$ are temporarily employed, while the rest is unemployed. According to the same research, if we look at age, unemployment is falling, and stable employment grows with the age of the young. Also, it was noticed that if we look at education, stable employment is rising, and unemployment falls with the higher educational level of a young person. Therefore, as a young person is older and more educated, the risk that this person will be unemployed is less.

Image 2.2: Categories of the employment of young by age and education (in \%)

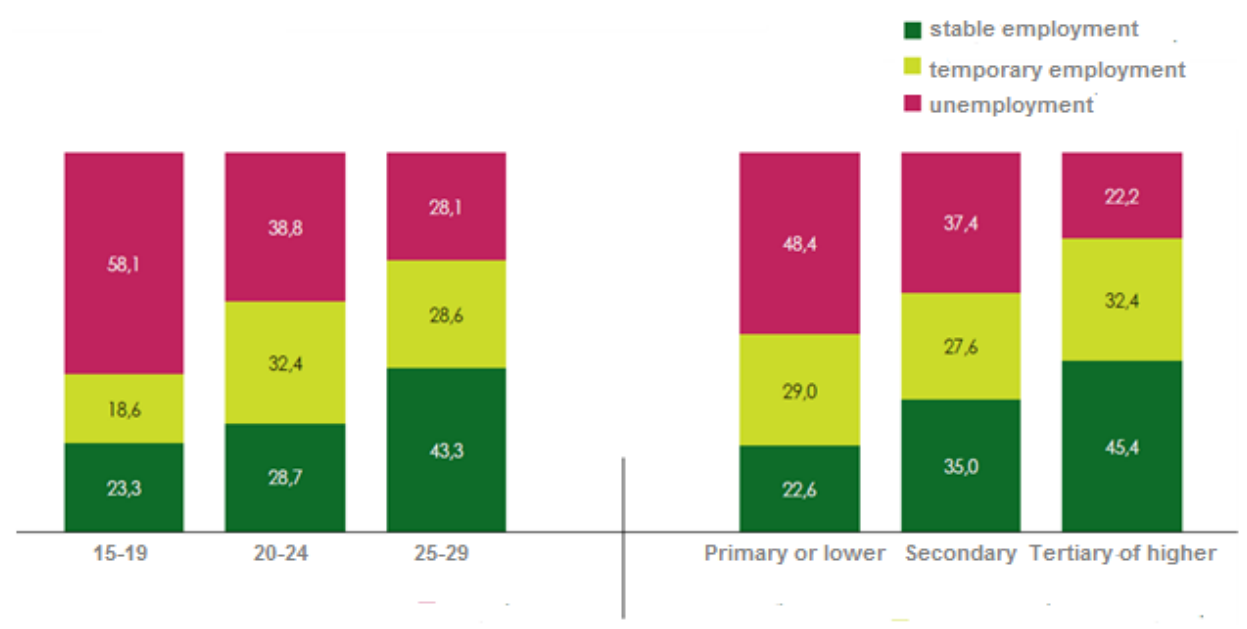

Source: Tomanovic et al. (2015)

Besides the difficulties in finding a stable job, a young person in Serbia, even when employed, receives a salary that is significantly lower than the average 
Vuksanović N. et. al.: School to work transition in Serbia: returns to investment in...

salary. The data from the Statistical Office of Serbia in 2015 indicate that the average monthly net salary for the young population was 29,500 RSD, while the average monthly net salary for the total population was 44,500 RSD. In other words, young people in Serbia received a salary in 2015 , which is 15,000 RSD less than the average salary. This unfavorable salary ratio is characteristic for young people in other European countries and it is in line with the theory, so Serbia is not an exception. As the age interval of the cohort of young people is rather narrowly defined and how it covers a large number of people who are still in the process of education, finding an employed young person to whom that job it's not the first employment or a young person with many years of working experience, is rare. Having in mind the results of more researches that show that the work experience, if we exclude the level of education, is the dominant determinant of earnings, it becomes clear why young people are in a subordinate position. However, one cannot ignore the fact that the phenomenon of relatively low salaries of the young population in relation to the total population is more pronounced in Serbia than in the countries of the European Union. One of the possible explanations is certainly the inadequate design of the tax system, primarily the tax on the income of citizens and within it, the tax on earnings. In the middle of last decade, Serbia reformed the tax system, and on that occasion, among other things, introduced a linear tax on citizens' income with the current valid rate of $10 \%$. In other words, different levels of income are taxed at the same rate, which makes the tax system proportionate. Extremely mild progressiveness, exclusively indirect progressiveness, ensures the existence of a non-taxed part of the profits. The tax system largely disincentives employers to hire workers in the lower part of the distribution of salaries because their total labor costs are relatively high. Therefore, as stated earlier, together with the lack of working experience, young people in Serbia are the majority of those who are on the very bottom of the income scale.

\section{Methodology}

In order to assess a rate of return to investment in education of young people in Serbia, the regression equation is estimated:

$$
\ln W_{i}=\alpha+\beta E U_{i}+\gamma E X P_{i}+\delta \operatorname{EXP}^{2}{ }_{i}+\varepsilon \operatorname{CON}_{i}+\zeta_{i}
$$

where:

(1) $W_{i}-$ a dependent variable represented as logarithmic value of a person's earnings $i$

(2) $\mathrm{EDU}_{\Gamma_{-}}$an independent variable represented as number of schooling years of a person $i$; 
Vuksanović N. et. al.: School to work transition in Serbia: returns to investment in...

(3) $\mathrm{EXP}_{\boldsymbol{T}}$ an independent variable represented as number of years of working experience of a person $i$;

(4) $\mathrm{EXP}^{2}{ }_{i}$ - an independent variable that represents the square of the number of years of working experience of a person $i$;

(5) $\mathrm{CON}_{i}$ - a set of control variables that relate to personal characteristics and characteristics of a person's job $i$.

This regression equation is known as an expanded function of earnings, or an expanded Mincer equation. The original Mincer equation represents the function of the logarithmic value of earnings exclusively from the number of years of schooling, the number of years of work experience and the square of the number of years of work experience.

Becker (1964) defined the school as an institution specialized in the production of training for those individuals who are studying. Namely, individuals usually do not find employment before they complete the education process, so the basic benefit of acquiring a certain educational level is to achieve higher profits in the future. At the same time, these individuals have to cover the costs of education in order to enjoy such benefits. The basic idea of Becker's model is that individuals must balance the benefits of acquiring a certain educational level and the costs associated with it, in order to make an optimal decision regarding the education process. Then, Mincer (1974) formulated an equation that was included in the model introduced by Becker (1964) and which introduces the function of earnings from an econometric perspective to describe the relationship between earnings and the number of years of schooling of an individual. What is specific about the form of this equation is the fact that Mincer added a variable that refers to the number of years of working experience. In this paper, Mincer points out that a simple equation in which earnings would be represented exclusively as a function of a variable that refers to the number of years of an individual's education could not properly include a link which is explored because education is not the only type of individual investing. Moreover, after investigating a large number of individual cases, Mincer argues that the function of earning is a concave function in relation to work experience. Therefore, Mincer added a variable to the equation which refers to both the number of years of work experience and the square of the number of years of work experience. This formulated equation describes the concave earnings curve over the life cycle of an individual, which indicates that the earnings of an individual fall with the increase in the number of years of work experience (Shi, 2016).

Miners' equation provides researchers with the possibility of assessing a rate of return to investing in education from a monetary perspective and allows direct comparison of the results. Empirical research on the impact of the educational level on earnings provides useful indicators, often in the form of 
Vuksanović N. et. al.: School to work transition in Serbia: returns to investment in...

projections of future earnings, which help individuals decide how much to invest in their own human capital. These indicators can also help policymakers in decision-making on policies related to educational investment. In this regard, it is not surprising that Mincer's equation is estimated in a large number of studies for different countries and different age groups. The simple form and stingy nature made Mincer's equation the most useful tool for studying the premium to education. Besides that, Mincer's equation is flexible, in that it enables researchers to include other variables, while still presents a precise method for modeling the relationship between earnings, educational level and work experience (Patrinos, 2016).

We shall estimate the equation (3.1) by the least squares method, in order to determine the average rate of return of young people in Serbia on investment in different levels of education. It should be kept in mind that the estimates of the Mincer equations obtained using the least squares method can bi subjected to potential endogenous problem. This problem, in this case, refers to the non-uniform value of covariates between the number of years of schooling and the individual's abilities, which can lead to the bias of the grades obtained. In particular, estimates obtained using the least squares method will be biased because more capable individuals tend to have higher levels of education and higher earnings. Therefore, the assessment of a rate of return to investment in education will only partially reflect the impact of the number of years of individual education, since an individual with a higher educational level is more capable, and this higher ability is not included in the equation which is assessed.

In order to overcome the potential endogenous problem, in the literature, the method of instrumental variables is pointed out as a possible solution. An instrumental variable is a variable that (1) is correlated with an independent variable EDUi, but (2) is not correlated with the standard error $\zeta$ i. The method of instrumental variables is a useful econometric tool when an independent variable is correlated with a standard error $\zeta$ i. Using this method allows researchers to establish a more precise relationship between the educational level and the earnings of the individual, as there are some other variables, such as the abilities of an individual, which may influence his choice of level of education, which is not included in the function of earnings. This method allows obtaining consistent estimates of a rate of return to education, by replacing the real values of the independent variable EDUi with the estimated values obtained from one or more instrumental variables. Card (2001) claims that the choice of the appropriate instrumental variables allows obtaining consistent estimates, but also that the choice of such variables which satisfy the requirement of high correlation with the independent variable EDUi and the condition of non-correspondence with the standard error $\zeta$ is extremely difficult. Moreover, according to Card (2001), in the case of selecting 
Vuksanović N. et. al.: School to work transition in Serbia: returns to investment in...

inadequate instrumental variables, the obtained estimates will be inconsistent and biased.

In a number of studies (e.g. Angrist and Krueger, 1990; Ashenfelter and Krueger, 1992; Card, 1993, Maluccio, 1998), researchers used as instrumental variables differences in the laws on compulsory education, the distance of higher education institutions, differences in the educational attainment of identical twins, educational level of parents. Of the aforementioned, as an interesting instrumental variable for researchers we could outline the educational level of the parents. The characteristics of the family from which the child comes from greatly influence the creation of the value of the human capital of this child since parents have a significant influence on the development of the child through various forms of support. Factors that greatly influence the efficiency of investing in the human capital of the child are financial stability, the promotion of educational values, the willingness of parents. Also, according to Altonji and Dunn (1996), the educational level of parents is highly correlated with the number of years of child education. Therefore, the choice of the educational level of parents as an instrumental variable for the number of years of education of an individual whose rate of return on investment in education is assessed seems to be appropriate. Having aforestated facts in mind, the equation (3.1) will be evaluated by the method of instrumental variables, and as the instrumental variables for the independent variable EDUi we shall use the level of education of the father (FEDUi) and the level of education of the mother (MEDUi).

As the sample of collected data is stratified, which will be discussed further, the weights from the sample were also used in the assessment.

\section{Data: school to work transition survey}

The estimation of a rate of return to investment for youth is based on the data from the School to Work Transition Survey (SWTS) for Serbia in 2015.

SWTS is a unique instrument that provides the generation of relevant information about people from 15 to 29 years old in the labor market of a particular country. The aforementioned survey, moreover, serves as a tool for researching transition paths towards stable and productive employment for young people. Namely, the International Labor Organization is committed to assisting economic policymakers and other social partners in identifying the problems that young people face today, as well as in creating and implementing integrated responses to identified problems. As one segment of this assistance, the International Labor Organization strives to strengthen the capacities of national and local institutions in conducting a research-based 
Vuksanović N. et. al.: School to work transition in Serbia: returns to investment in...

analysis, which would enable social dialogue and the process of creating economic policy. Having in mind (1) that existing labor market restrictions on the labor market often prevented the provision of satisfactory explanations of the increasingly lengthy and difficult process of transition from finishing school to finding a job; (2) the significant improvement of this transition process is among the priorities in the agenda of economic policymakers in an increasing number of countries; and (3) the strengthening of the information base is a key step towards designing and controlling the proper functioning of young people. The International Labor Organization has developed the SWTS (Matsumoto and Elder, 2010). In other words, the International Labor Organization has prepared the SWTS in order to help countries in which this survey is conducted to build a youth employment database and provide information necessary for more effective sector policy development. It should be kept in mind that the Quarterly Labor Force Survey already provides basic information about young people in the labor market, but it certainly does not manage to provide more detailed information on youth employment. The transition from school to work survey should just clarify these details. These details should facilitate economic policymakers focusing on direct and longterm actions that are necessary in order to facilitate the transition of young people (Marjanovic, 2016).

For the first time in 2015, Serbia implemented the SWTS under the Work4Youth Project. The Work4Youth Project was created as a result of the partnership of the Employment Program of the International Labor Organization and the MasterCard Foundation. The budget of this project is 14.6 million USD. The project is time-limited for five years, with the planned completion in mid-2016. The goal of the project is "creating opportunities for dignified employment of young men and women through knowledge and action". The partnership of these two organizations should produce more and better information specific to young people in developing countries, with a particular focus on the transition paths in the labor market. The assumption is that economic policymakers and social partners in the countries to which the project focuses will be better prepared in terms of developing an effective sectoral policy.

Data collection and sampling was carried out by the Serbian Statistical Office, while the International Labor Organization provided a standardized survey instrument. Fieldwork was carried out during March and April 2015, and in that period, about 3,100 persons from 15 to 29 years old were interviewed. In selecting the sample, a two-stage stratification method was used, relying on the census data from 2011. The first stratum is the numbering areas, while the second stratum is represented by households, i.e. young people in them. The numbering areas, as the first instance for sampling units, are divided according to the type of settlement (urban or rural) and according to the territory based on the nomenclature of territorial statistical units (Belgrade, 
Vuksanović N. et. al.: School to work transition in Serbia: returns to investment in...

Vojvodina, Sumadija and Western Serbia or South and Eastern Serbia). Numbering areas were selected systematically with a probability which is proportional to the estimated number of young people from 15 to 29 years old. It should be noted that a high level of implicit geographical stratification was achieved, which ensured effective distribution of the sample. Subsequently, households, as the second instance for sampling units, were selected in the previously selected numbering areas with the same probability. In each of them, in this way chosen young people are exclusively interviewed (International Labour Organization, 2017b).

Such collected and sampled data on young people should serve for a number of purposes to economic policymakers in Serbia. First, data allows the detection of personal characteristics of those young people who are in a particularly unfavorable position on the labor market. Secondly, the data enable identification of characteristics of demand and supply in the youth labor market, which will help in determining (non)compliance in terms of educational qualifications and qualifications required for a particular job. Third, given the insufficient development of the labor market information system, youth data provide a reliable basis for monitoring progress in achieving the Millennium Development Goals (MDGs) of the United Nations. SWTS is designed to fill in a collection for a young person who completes the survey, specifically: (1) general information, i.e. information related to personal characteristics, the characteristics of the family from which the person originates, education and aspirations, and (2) information on the current economic activity in the labor market, or information concerning whether a person is still studying, is employed or unemployed, whether it is outside the workforce and has completed schooling. The survey consists of 7 sections, in which young people provide answers to over 200 questions. Without these data, a number of studies that monitor the transition of young people to determine the factors that influence the ease and (un)success of this time could not be carried out (International Labour Organization, 2017a).

\section{Results and Discussion}

The results of the assessment of a rate of return to investment in education of young people in Serbia obtained by the least squared method are presented in Table 5.1.

The results of the assessment using the least squares method indicate that a rate of return to investment in youth education in Serbia is $5.2 \%$, i.e. that every additional year of education, on average, increases the value of the earnings of the young person for that percentage. The resulting value of a rate of return to investment in education is somewhat similar to the results 
Vuksanović N. et. al.: School to work transition in Serbia: returns to investment in...

obtained in other surveys. For example, Pastore (2009) has found that a rate of return to investment in youth education in Mongolia is $4.2 \%$ based on the data from the SWTS in 2006 using the least squares method. Moreover, the positive value of the coefficient with the variable referring to the number of years of working experience and the negative value of the coefficient with the variable referring to the square of the number of years of working experience confirm that the function of earning is a concave function in relation to the youth work experience in Serbia. More precisely, each additional year of working experience increases the earnings of a young person on average by around $3.5 \%$. The effect then decreases with the number of years of work experience gained after reaching a certain level.

Table 5.1: The estimation of the return on investment in education for youth in Serbia obtained using the least squares method

\begin{tabular}{|l|c|}
\hline \multicolumn{1}{|c|}{ Variable } & Coefficient \\
\hline Number of years of schooling & $0.0522(0.0033)^{\star}$ \\
\hline Number of years of working experience & $0.0356(0.0120)^{\star}$ \\
\hline $\begin{array}{l}\text { Square of number of years of working } \\
\text { experience }\end{array}$ & $-0.0021(0.0008)^{\star *}$ \\
\hline Male & $0.0440(0.0188)^{\star}$ \\
\hline A person lives in urban area & $0.0347(0.0152)^{\star}$ \\
\hline A person is married & $0.1224(0.0329)^{\star}$ \\
\hline A person has children & $-0.0987(0.0334)^{\star}$ \\
\hline A person has a long-term contract & $0.0489(0.0190)^{*}$ \\
\hline A full-time employee & $0.1450(0.0561)^{*}$ \\
\hline Number of working hours & $0.0005(0.0001)^{\star}$ \\
\hline A person is a member of syndicate & $0.0554(0.0194)^{\star *}$ \\
\hline A person had a training & $0.0352(0.0166)^{\star}$ \\
\hline A person is satisfied with a job & $0.1081(0.0286)^{\star}$ \\
\hline Constant & $3.6951(0.0916)^{\star}$ \\
\hline Adjusted $\mathrm{R}^{2}$ & 0,33 \\
\hline
\end{tabular}

\section{Notes:}

(1) Robust standard error in brackets;

(2) Statistically significant at the level of $0.01\left(^{*}\right)$;

(3) Statistically significant at the level of $0.05\left(^{* *}\right.$;

(4) Statistically significant at the level of $0,10\left(^{* * *}\right)$.

Source: Authors' calculation

According to the results obtained by the least squares method, the influence of other control variables related to personal characteristics and characteristics of youth work in Serbia is statistically significant and with the expected sign. In regard to the personal characteristics of young people, the results suggest that there is a difference in earnings in the terms of sex since males have earnings which are about $4.4 \%$ higher than for females. This is in line with the results established in the previous research. For example, 
Vuksanović N. et. al.: School to work transition in Serbia: returns to investment in...

Arandarenko et al. (2006), assessing the value of human capital in the Balkan countries in transition, found for Serbia that males for each level of education achieves higher earnings than females. The following facts should be considered in regard to this result: (1) research covers the total population, not the young population; (2) research refers to the rate of return at different educational levels rather than the rate of return by year of schooling. Further, the results show that the earnings of young people living in urban areas are higher by about $3.5 \%$. Also, young people who are married and who do not have children have earnings which are on average higher by $12.2 \%$ and $9.8 \%$ respectively. In regard to the characteristics of young people's jobs, according to the results obtained, we can say that young people with a long-term contract have a salary of $4.8 \%$ higher on average. Young people working fulltime on average get earnings of $14.5 \%$ higher than those working part-time, and every extra hour of work increases the earnings of young people by $0.05 \%$ on average. As expected, young people who are members of the syndicates, who have been trained and who are satisfied with the job earn on average a $5.5 \%, 3.5 \%$, and $10.8 \%$ higher salary, respectively. Consequently, according to the high value of the coefficient related to the job satisfaction, we can say that this result suggests that the feeling of satisfaction at work is of special significance for young people in Serbia.

Table 5.2 shows the results of a rate of return to investment in education for youth in Serbia obtained using instrumental variables method. More precisely, the method of two-stage least squares was applied. A father's level of education and a mother's level of education are variables which are chosen as instruments for the number of years of schooling. This choice of instruments was made in accordance with the results of other studies (e.g. Card, 1993; Maluccio, 1998; Pastore, 2009; Shu, 2016), where the researchers used this method of assessment and concluded that number of years of schooling a child is correlated with the educational level of the parents of that child. Moreover, in these studies, it was found that rates of return on investment in education obtained using instrumental variables method were greater than rates of return to investment in education obtained through the application of the least squares method. This confirms that in the case of the assessment established by least squares method, the rate of return on investment in education is biased (Psacharopoulos and Patrinos, 2004).

Before presenting the results of the assessment of the rate of return to investment in education of youth in Serbia obtained using the instrumental variables method, it should be noted that it was examined whether this method is justified. In other words, the endogenous test of a variable was performed. The value of the Wu-Hausman statistic test suggests that variable are endogenous and that it is justified to use the instrumental variables method. It was also examined whether the chosen instruments satisfy the 
Vuksanović N. et. al.: School to work transition in Serbia: returns to investment in...

premise that the educational level of father and mother is correlated with the number of years of schooling of the young person. The value of Wald statistic test indicates that the chosen instruments are not weak, i.e. that a father's level of education and a mother's level of education are highly correlated with the number of years of young people in Serbia.

Table 5.2: The estimation of the return on investment in education for youth in Serbia obtained using the method of instrumental variables

\begin{tabular}{|l|c|}
\hline \multicolumn{1}{|c|}{ Variable } & Coefficient \\
\hline \multicolumn{1}{|c|}{ Logarithmic value of earning } \\
\hline Number of years of schooling & $0.0933(0.0080)^{\star}$ \\
\hline Number of years of working experience & $0.0358(0.0115)^{\star}$ \\
\hline $\begin{array}{l}\text { Square of number of years of working } \\
\text { experience }\end{array}$ & $-0.0026(0.0008)^{\star *}$ \\
\hline Male & $0.0455(0.0219)^{*}$ \\
\hline A person lives in urban area & $0.0368(0.0195)^{\star *}$ \\
\hline A person is married & $0.1226(0.0322)^{\star}$ \\
\hline A person has children & $-0.0976(0.0333)^{\star}$ \\
\hline A person has a long-term contract & $0.0490(0.0187)^{*}$ \\
\hline A full-time employee & $0.1449(0.0550)^{\star}$ \\
\hline Number of working hours & $0.0005(0.0001)^{\star}$ \\
\hline A person is a member of syndicate & $0.0547(0.0205)^{\star}$ \\
\hline A person had a training & $0.0343(0.0185)^{\star \star}$ \\
\hline A person is satisfied with a job & $0.1080(0.0286)^{\star}$ \\
\hline Constant & $3.6804(0.1151)^{*}$ \\
\hline Adjusted R & 0,34 \\
\hline
\end{tabular}

Notes:

(1) Robust standard error in brackets;

(2) Statistically significant at the level of $0.01\left(^{*}\right)$;

(3) Statistically significant at the level of $0.05\left(^{* *}\right)$;

(4) Statistically significant at the level of $0,10\left(^{* * *}\right)$;

(5) Instruments for 'number of years of schooling variable': educational level of father, educational level of mother.

Source: Authors' calculation

The assessment results using the method of instrumental variables show that a rate of return to investment in education for youth in Serbia is $9.3 \%$, so that each additional year of schooling increases the value of earned youth income by slightly over $9 \%$. The value of the coefficient in the case of evaluation by the instrumental variables method is twice as big as in the case of the least squares method. This result, according to the previous explanation, is expected and confirms the justification of the use of a father's level of educationand a mother's level as instruments for the number of years of education of a young person in Serbia. It also suggests that schooling of children in Serbia continues to serve as a family characteristic, and informs that the education system in Serbia cannot provide a fair access to schooling 
Vuksanović N. et. al.: School to work transition in Serbia: returns to investment in...

for those children coming from socio-economic vulnerable families. Moreover, the value of a rate of return to investment in education for youth in Serbia is similar to the results of other researchers. For example, Shi (2016) estimating a rate of return to investment in education for young people in the United States also came to the conclusion that the estimates obtained using the instrumental variables method were almost twice as high as those obtained using the least squares method, since the values of the estimated coefficients are, respectively, $10.2 \%$ and $5.8 \%$. Pastore (2009) also came up with a similar result. He found that the evaluation by instrumental variables method yields a significantly higher coefficient value with a change in the number of years of schooling. Namely, the estimated values of a rate of return to investment in education for youth in Mongolia are $4.2 \%$, in the case of using the least squares method, and $10.8 \%$, in the case of using the method of instrumental variables.

It should also be pointed out that, according to the results obtained by the instrumental variables method, the influence of the variables concerning to the number of years of working experience and the square of the number of years of working experience, as well as the influence of other control variables, is statistically significant and with the expected sign. Moreover, the values of the coefficients with these variables in Table 5.2 do not differ significantly from those in Table 5.1.

\section{Conclusion}

Although numerous studies have been carried out to assess a rate of return to investment in education for a particular country or region, only a small number of researches tried to assess this rate for certain groups within the total population. In other words, only a small number of surveys have been devoted to assessing a rate of return to investment in education of the young population as a special group.

In this paper, the research that has been conducted has a goal of assessing a rate of return to investment in education for youth in Serbia. The significance of this paper is reflected in the fact that this is the first research of this type, since so far there's no literature where the premium on the education of exclusively young people as a special group on the Serbian labor market is studied. In this connection, an expanded earning function, i.e. expanded Mincer equation, has been estimated. More precisely, the logarithm of earnings is observed as a function of variables which are related to the number of years of schooling, the number of years of working experience, the square of number of years of working experience and the control variables that relates to the personal characteristics and characteristics of a person's 
Vuksanović N. et. al.: School to work transition in Serbia: returns to investment in...

job. The analysis was conducted based on data from SWTS for Serbia in 2015. Data collection and sampling was carried out by the Statistical Office of Serbia, while the International Labor Organization provided a standardized survey tool. SWTS in Serbia was carried out during March and April 2015, and in that period, about 3,100 persons from 15 to 29 years old were interviewed, which makes the sample on which the analysis was conducted.

A rate of return to investment in education for youth is estimated using the least squares method and using the instrumental variables method. As the instruments for a variable that refers to the number of years of education were used a father's level of education and a mother's level of education. The conducted tests confirmed the justification of the instrumental variables method and the positive significant correlation between the number of years of education of young person and the parent's level of education of that person. Also, since the sample is based on the data collected from the SWTS, sample weights were used in the analysis.

The results of the assessment using the least squares method indicate that a rate of return to investment in education for youth in Serbia is $5.2 \%$, while the rate of assessment using the the instrumental variables method is $9.3 \%$. It is confirmed that in the case of the assessment using the least squares method we get a biased assessment. Also, the gained results of the rates of return on investment in education for young people in Serbia are similar to the results that other researchers have gotten in studies conducted for other countries.

The positive value of the coefficient with the variable referring to the number of years of working experience and the negative value of the coefficient with the variable referring to the square of the number of years of working experience indicate that the function of earnings is a concave function in relation to the young people's working experience in Serbia. The influence ofother control variables related to the personal characteristics and characteristics of a person's job, based on the evaluation of the least squares method and instrumental variables method, is statistically significant with the expected sign. Moreover, the value of the coefficients with these variables is not significantly different with respect to the method applied.

\section{References}

Altonji, J.G., \& Dunn, T.A. (1996). The Effects of Family Characteristics on the Return to Education. The Review of Economics and Statistics, 78(4), 692. doi:10.2307/2109956

Arandarenko, M., \& et al., (2006). Valuing human capital in Balkan transition countries. Center for Economic Research / Graduate Education and the Economics Institute.

Becker, G. (1964). Human Capital. The University of Chicago Press. 
Vuksanović N. et. al.: School to work transition in Serbia: returns to investment in...

Biavaschi, C., \& et al., (2012). Youth Unemployment and Vocational Training. IZA World of Labor. 6890.

Card, D. (2001). Estimating the Return to Schooling: Progress on Some Persistent Econometric Problems. Econometrica,69(5), 1127-1160. doi:10.1111/14680262.00237

Du Bois-Reymond, M., \& Chisholm, L. (2006). Young Europeans in a changing world. In M. du Bois-Reymond \& L. Chisholm (Eds.), The Modernisation of Youth Transitions in Europe: New Directions for Child and Adolescence Development. (pp. 1-10). Routledge.

Elder, S. (2009). School to work transition survey: Basic concepts, roles, and implementation process. International Labor Office.

-Eurofound. (2014). Mapping youth transitions in Europe. Publications Office of the European Union.

Furlong, A., \& Cartmel, F. (2007). Young People and Social Change. Individualisation and Risk in Late Modernity. Open University Press.

Harmon, C., Oosterbeek, H., \& Walker, I. (2003). The Returns to Education: Microeconomics. Journal of Economic Surveys, 17(2), 115-156. doi:10.1111/1467-6419.00191

Joksimovic, Lj. \& Vuksanovic, N. (2017). World phenomenon of lack of traditional jobs and the increase of income inequality as its consequences. In Grk. S. (Ed.). World and Serbia - Challenges and Temptations (pp. 41-58). Institute of Social Sciences.

Kluve, J. (2014). Youth market labor interventions. IZA World of Labor, doi:10.15185/izawol.106

Marjanovic, , \& et al., (2016). Evaluacije paketa usluga za mlade i relevantnih programa i mera finansiranih iz budžeta Vlade Republike Srbije koji su usmereni ka mladima. Fondacija za razvoj ekonomskih nauka.

Marjanovic, D. (2016). Labour market transitions of young women and men in the Republic of Serbia. Work4Youth Publication Series, 36.

Matsumoto, M., \& Elder, S. (2010). Characterizing the school-to-work transitions of young men and women: Evidence from the ILO School-to-work transition surveys. Employment Working Paper, No. 51.

Mincer, J. (1974). Schooling, Experience, and Earnings. National Bureau of Economic Research.

Montenegro, C.E., \& Patrinos, H.A. (2014). Comparable Estimates of Returns to Schooling around the World. World Bank. Policy Research Working Paper. doi:10.1596/1813-9450-7020

Mortimer, J.T. (2009). Changing Experiences of Work. In A. Furlong (Ed.), Handbook of Youth and Young Adulthood: New Perspectives and Agendas. Routledge. pp. 95-96.

Pastore, F. (2009). School to work transition in Mongolia. The European Journal of Comparative Economics, 6 (2), pp. 245-264.

Patrinos, H. (2016). Estimating the return to schooling using the Mincer equation. IZA World of Labor,doi:10.15185/izawol.278

Psacharopoulos, G., \& Patrinos, H.A. (2004). Returns to investment in education: a further update. Education Economics, 12(2), 111-134. doi:10.1080/0964529042000239140

Schultz, T. (1961). Investment in Human Capital. The American Economic Review, 51(1), pp. 1-17. 
Vuksanović N. et. al.: School to work transition in Serbia: returns to investment in...

Shi, Z. (2016). Effects of Parental Education on Return to Education. Economics Student Theses and Capstone Projects. Retrieved from http://creativematter.skidmore.edu/econ_studt_schol/1/..

Sparreboom, T., \& Staneva, A. (2014). Is education the solution to decent work for youth in developing economies?. Work4Youth Publication Series, 23.

Tomanovic, , \& et al., (2015). Mladi u Srbiji 2015. Stanja, opažanja, verovanja $i$ nadanja. Friedrich Ebert Stiftung / SeConS Grupa za razvojnu inicijativu.

Vuksanovic, N. \& Aleksic, D. (2017). Investment in education as a way of overcoming the problem of information asymmetry in the labour market. Economic Themes, 55 (3), pp. 377-397.

-World Bank. (2006). Serbia: Labor Market Assessment. Report No. 36576-YU.

Wyn, J. (2009). Educating for Late Modernity. In A. Furlong (Ed.), Handbook of Youth and Young Adulthood: New Perspectives and Agendas. Routledge. pp. 97-103.

-International Labour Organization. (2017). School to work transition survey: $A$ methodological guide. Module 2. Retrieved from http://www.ilo.org/wcmsp5/groups/public/@ed_emp/documents/instructionalmate $\mathrm{rial} / \mathrm{wcms} 140858 . p d f .$.

-International Labour Organization. (2017). School to work transition survey: $A$ methodological guide. Module 3. Retrieved from http://www.ilo.org/wcmsp5/groups/public/@ed_emp/documents/instructionalmate $\mathrm{rial} / \mathrm{wcms}$ 140859.pdf..

-Ministarstvo finansija Republike Srbije - Poreska uprava, (2017). Zakon o porezu na dohodak građana. Retrived from http://www.poreskauprava.gov.rs/pravnalica/pregled-propisa/zakoni/172/zakon-o-porezu-na-dohodak-gradjana.html.. 